\title{
Efek dari Kombinasi Pupuk N, P dan K terhadap Pertumbuhan dan Hasil Kacang Tanah pada Lahan Kering Alfisol
}

\author{
Effect of N, P and K Fertilizer Combinations to Growth and Yield of Peanut on \\ Alfisols Dry Land
}

\author{
Desi Arista $^{1)}$, Suryono ${ }^{2)}$, Sudadi ${ }^{2)}$
}

\begin{abstract}
This study was aimed to determine the effect of fertilizer dose combination of $\mathrm{N}, \mathrm{P}$, and $\mathrm{K}$ on growth and yield of peanut on Alfisols dryland. The experiment was conducted from April to September 2014 in Sukosari Village, Jumantono, Karanganyar with 3 factor completely randomized design arranged $\mathrm{N}$ (Urea) fertilizer dose $(50,100,150) \mathrm{kg} \mathrm{ha}^{-1}, \mathrm{P}(\mathrm{SP}-36)$ fertilizer dose $(100,200,300) \mathrm{kg} \mathrm{ha}^{-1}$ and $\mathrm{K}(\mathrm{ZK})$ fertilizer dose $(75,150,225) \mathrm{kg}$ $\mathrm{ha}^{-1}$. Statistical analysis using $\mathrm{F}$ test $5 \%$ followed by DMRT with $95 \%$ confidence level. The parameters observed were wet and dry weight of plant per sample, number of filled pods per sample, weight of pods per sample, and weight of dry seed per sample. Fertilizer dose combination of N, P and K significantly affect on dry weight. Fertilizer dose combination $\mathrm{N}$ and $\mathrm{P}$ significantly affect on number of filled pods and weight of pods per sample. Combination of $\mathrm{P}$ and $\mathrm{K}$ fertilizers significantly affect on dry seed weight. $\mathrm{N}$ fertilizer dose significantly affect on weight of dry seed per sample. The best fertilizer dose combination is $\mathrm{P}_{3} \mathrm{~K}_{3}$ treatment $\left(300 \mathrm{~kg} \mathrm{ha}{ }^{-1}\right.$ and $225 \mathrm{~kg} \mathrm{ha}^{-1}$ ) that can increased $57 \%$ weight of dry seed if compared with recommendation dose.
\end{abstract}

Key words : fertilizer dose combination, alfisol soil, peanuts

\section{PENDAHULUAN}

Kebutuhan kacang tanah dalam negeri dari tahun ke tahun semakin meningkat. Kebutuhan kacang tanah terus meningkat rata-rata 900.000 ton/tahun, sedangkan produksi rata-rata hanya 771.022 ton/tahun $(85,67 \%)$ dengan volume impor rata-rata 163.745 ton/tahun. Rata-rata pertahun untuk luas panen berkurang 2,28 \% sedangkan produksi berkurang 1,02 \%. Data tersebut menunjukkan produksi kacang tanah perlu ditingkatkan (Direktorat Jenderal Tanaman Pangan 2012).

Budidaya kacang tanah sebagian besar $(70-80 \%)$ dilakukan di lahan kering (Harsono et al. 1993). Lahan kering tanah Alfisol mempunyai keunggulan sifat fisika yang relatif bagus, tetapi tanah Alfisol miskin hara $\mathrm{N}$, $\mathrm{P}$ dan $\mathrm{K}$ akibat kandungan humus yang sangat rendah. Unsur hara tanah Alfisol mudah berikatan dengan ion $\mathrm{Al}^{2+}$ dan $\mathrm{Fe}^{3+}$ dan tingkat pelapukan yang tinggi menyebabkan hara di dalam tanah Alfisol mudah terlindi.

Unsur hara N, P dan K merupakan unsur hara utama untuk pertumbuhan kacang tanah. Unsur $\mathrm{N}$ merupakan unsur hara yang berperan untuk pembentukan organ vegetatif tanaman dan merupakan unsur utama pembentuk asam amino dan protein. Hara $\mathrm{K}$ sangat penting dalam proses pembentukan biji kacang tanah bersama hara $\mathrm{P}$ disamping juga penting sebagai pengatur berbagai mekanisme dalam proses metabolik seperti

1) Undergraduate Student of Study Program of Agrotechnology, Faculty of Agriculture, University of Sebelas Maret (UNS) in Surakarta.

2) Lecturer Staff at Study Program of Agrotechnology, Faculty of Agriculture, University of Sebelas Maret (UNS) in Surakarta.

Contact author : suryono_uns@yahoo.com fotosintesis, transportasi hara dari akar ke daun, translokasi asimlat dari daun ke seluruh jaringan tanaman (Sutarto et al.1988).

Rekomendasi pemupukan kacang tanah pada lahan kering Alfisols selama ini belum mengacu pada kombinasi dosis pupuk $\mathrm{N}, \mathrm{P}$ dan $\mathrm{K}$ sehingga perlu diteliti bagaimana kombinasi dosis pemupukan $N, P$ dan $\mathrm{K}$ yang tepat bagi tanaman kacang tanah. Penelitian ini bertujuan untuk mengetahui pengaruh kombinasi dosis pupuk N, $\mathrm{P}$, dan $\mathrm{K}$ terhadap pertumbuhan dan hasil tanaman kacang tanah pada lahan kering Alfisols sehingga diperoleh kombinasi dosis pupuk $\mathrm{N}, \mathrm{P}$ dan $\mathrm{K}$ yang tepat untuk meningkatkan pertumbuhan dan hasil kacang tanah pada lahan kering Alfisols.

\section{METODE PENELITIAN}

Penelitian ini dilaksanakan pada bulan April sampai September 2014 di Lahan Kering Alfisols Desa Sukosari, Kecamatan Jumantono, Kabupaten Karanganyar. Bahan yang digunakan dalam penelitian ini adalah benih kacang tanah varietas lokal, pupuk SP-36, pupuk ZK dan pupuk Urea, pupuk kandang, bahan kimia untuk analisis kimia tanah meliputi $\mathrm{K}_{2} \mathrm{Cr}_{2} \mathrm{O}_{7}, \mathrm{H}_{2} \mathrm{SO}_{4}, \mathrm{NH}_{4} \mathrm{OAc}, \mathrm{NaCl}, \mathrm{KCL}$, alkohol dan lain sebagainya. Alat yang digunakan dalam penelitian ini yaitu cangkul, tugal, meteran, penggaris, timbangan analitik, oven serta alat untuk analisis kimia tanah meliputi timbangan, tabung reaksi, $\mathrm{pH}$ meter, spektofotometer, tabung kjedahl, oven dan lain-lain.

Penelitian ini menggunakan Rancangan Acak Lengkap (RAL) dengan 3 faktor. Faktor pertama adalah pupuk $\mathrm{N}$ (Urea) dengan 3 taraf yaitu $\mathrm{N} 1=50 \mathrm{~kg}$ $\mathrm{ha}^{-1}, \mathrm{~N} 2=100 \mathrm{~kg} \mathrm{ha}^{-1}$ dan N2=150 kg ha ${ }^{-1}$, faktor kedua adalah pupuk $\mathrm{P}$ (SP-36) yaitu $\mathrm{P} 1=100 \mathrm{~kg} \mathrm{ha}^{-1}$, $\mathrm{P} 2=200 \mathrm{~kg} \mathrm{ha}^{-1}$ dan $\mathrm{P} 3=300 \mathrm{~kg} \mathrm{ha}^{-1}$, faktor ketiga

Efek dari Kombinasi Pupuk N, P dan K terhadap Pertumbuhan ...................

Suryono, Sudadi, Desi Arista 
adalah dosis pupuk $\mathrm{K}(\mathrm{ZK})$ yaitu $\mathrm{K} 1=75 \mathrm{~kg} \mathrm{ha}^{-1}$, $\mathrm{K} 2=150 \mathrm{~kg} \mathrm{ha}^{-1}$ dan $\mathrm{K} 3=225 \mathrm{~kg} \mathrm{ha}^{-1}$.

Pelaksanaan penelitian meliputi persiapan lahan, pemupukan diawali dengan dengan pupuk kandang sebagai pupuk dasar, kemudian kombinasi pupuk perlakuan diberikan sekaligus pada masing-masing petak sesuai dengan dosis yang diuji dengan mencampur ketiga pupuk pada tanah sampai merata pada masing-masing petakan. Penanaman dilakukan dengan setiap lubang ditanami dua benih kacang tanah. Jarak antar tanam $25 \mathrm{~cm} \times 20 \mathrm{~cm}$. Pemanenan dilakukan saat tanaman berumur 85 HST. Variabel yang diamati adalah berat segar brangkasan per tanaman, berat brangkasan kering per tanaman, jumlah polong isi per tanaman, berat polong isi per tanaman dan jumlah biji kering per tanaman. Analisis statistik menggunakan uji $F$ 5\% dilanjutkan dengan uji beda nyata jujur dengan taraf kepercayaan $95 \%$.

\section{Analisis Tanah Awal}

Berdasarkan hasil analisis tanah awal, dapat dijelaskan bahwa tanah Alfisol memiliki kadar bahan organik, KPK, N-Total, $\mathrm{K}$ Tersedia rendah dan $\mathrm{P}$ tersedia tanah Alfisol sangat rendah. Rendahnya hasil analisis tanah tersebut menunjukkan bahwa kesuburan tanah rendah. Hal ini sesuai dengan pernyataan Minardi (2002) menjelaskan bahwa $\mathrm{pH}$, $\mathrm{BO}, \mathrm{KTK}$, dan $\mathrm{P}$ tersedia rendah merupakan indikasi kesuburan tanah yang rendah. Kandungan hara yang rendah pada tanah Alfisol ini akibat dari unsur hara seperti $\mathrm{P}$ yang mudah berikatan dengan ion $\mathrm{Al}^{2+}$ dan $\mathrm{Fe}^{3+}$. Tanah Alfisol merupakan tanah yang mengalami tingkat pelapukan tinggi yang menyebabkan hara di dalam tanah terlindi. Tanah Alfisol memiliki kandungan ion $\mathrm{H}_{+}$dalam jumlah yang lebih banyak dibanding $\mathrm{OH}-$, selain itu tingkat pelapukan yang tinggi serta adanya unsur besi pada tanah Alfisol menyebabkan $\mathrm{pH}$ tanah masam.

\section{HASIL DAN PEMBAHASAN}

Tabel 1. Beberapa sifat tanah alfisol di lahan percobaan

\begin{tabular}{llll}
\hline Variabel & Satuan & Nilai & Keterangan \\
\hline pH & - & 5,4 & Masam $^{*}$ \\
Bahan Organik & $\%$ & 1,01 & Rendah $^{*}$ \\
KPK & me\% & 15,7 & Rendah* $^{*}$ \\
N Total & $\%$ & 0,12 & Rendah* $^{*}$ \\
P Tersedia & ppm & 2,3 & Sangat Rendah* \\
K Tersedia & me\% & 0,2 & Rendah* $^{*}$ \\
\hline
\end{tabular}

Keterangan: *Pengharkatan Tanah Menurut Balai Penelitian Tanah Bogor 2005.

Sumber: Hasil analisis Laboratorium Kimia dan Kesuburan Tanah FP UNS 2014.

\section{Berat Segar Brangkasan/tanaman}

Berdasarkan hasil analisis ragam, dapat diketahui bahwa pemberian dosis pupuk $\mathrm{N}$ berpengaruh terhadap berat segar brangkasan. Berdasarkan diagram di atas dapat diketahui bahwa semakin banyak pupuk $\mathrm{N}$ yang diberikan maka berat segar brangkasan semakin meningkat. Hal ini dapat disebabkan karena nitrogen merupakan unsur yang berfungsi sebagai pembentuk bagian vegetatif tanaman. Hal ini sesuai dengan pendapat Sumampow (2009) yang mengatakan bahwa nitrogen merupakan bahan penting menyusun asam amida, nukleotida, nukleoprotein serta penting bagi pembelahan dan pembesaran sel sehingga nitrogen sangat berperan dalam pertumbuhan tanaman.

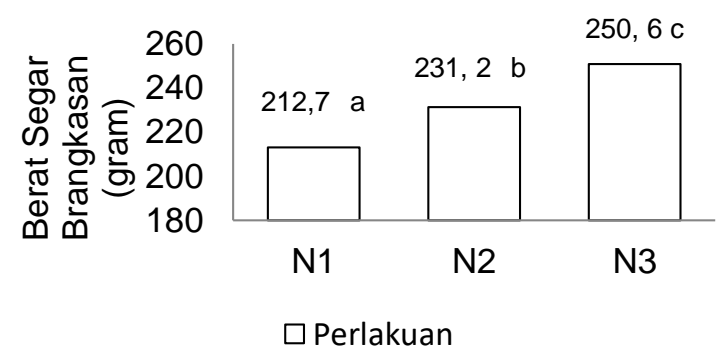

Gambar 1. Pengaruh kombinasi dosis pupuk $\mathrm{N}$ terhadap berat segar brangkasan/ tanaman (gram).
Adapun perlakuan yang paling baik untuk meningkatkan hasil berat segar brangkasan yaitu pupuk Nitrogen dengan dosis $150 \mathrm{~kg} \mathrm{ha}^{-1}$. Hal ini diduga pada perlakuan tersebut kebutuhan $\mathrm{N}$ telah tersedia dan tercukupi untuk pertumbuhan tanaman kacang tanah. Hal ini sesuai dengan pendapat Lingga (1994) menyatakan bahwa unsur nitrogen bagi tanaman dapat merangsang pertumbuhan tanaman secara keseluruhan khususnya batang dan daun. Selanjutnya Gardner et al. (1991) menambahkan bahwa secara umum penggunaan nitrogen pada tanaman mampu menghasilkan pertumbuhan vegetatif yang lebih cepat, meningkatkan panjang batang, memperbesar ukuran daun dan memberikan warna daun lebih hijau. Menurut Prawinata et al. (1991) pemberian unsur nitrogen dapat meningkatkan laju fotosintesis tanaman sehingga dapat memacu pertumbuhan vegetatif. Peningkatan jumlah nitrogen akan menghasilkan protein dalam jumlah banyak pada tanaman, sehingga meningkatkan pertumbuhan jaringan tanaman dan berat tanaman juga meningkat.

\section{Jumlah Polong isi /tanaman}

Berdasarkan hasil analisis ragam, dapat diketahui bahwa kombinasi dosis pupuk $\mathrm{N}$ dan $\mathrm{P}$ berpengaruh nyata terhadap jumlah polong. Berdasarkan diagram tersebut, dapat diketahui bahwa hasil jumlah polong tertinggi pada perlakuan $\mathrm{N}_{2} \mathrm{P}_{3}$ yaitu pemupukan urea dengan dosis $100 \mathrm{~kg}$ ha-1 dan dan SP-36 dengan 
dosis 300 kg ha-1. Hal ini menunjukkan pupuk $\mathrm{N}$ dan $P$ yang cukup dalam pembentukan polong kacang tanah.

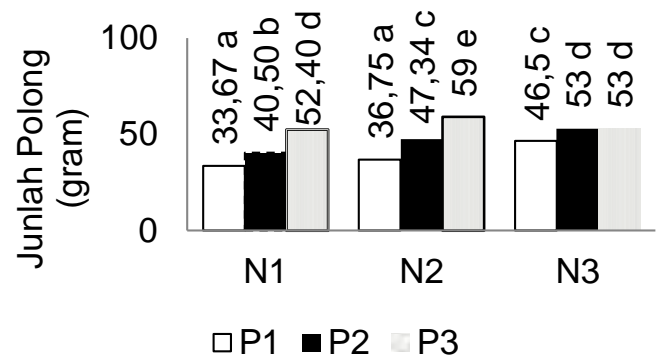

Gambar 2. Pengaruh kombinasi dosis pupuk N dan $P$ terhadap jumlah polong isi /tanaman

Unsur $\mathrm{N}$ dan $\mathrm{P}$ merupakan unsur hara esensial yang berperan dalam pembentukan polong kacang tanah. Tersedianya hara $\mathrm{P}$ akan menyebabkan proses fotosintesis berjalan lancar sehingga pemupukan $\mathrm{N}$ dengan dosis $100 \mathrm{~kg} \mathrm{ha}^{-1}$ dapat diserap tanaman untuk fotosintesis dan menghasilkan polong yang terisi penuh. Unsur $\mathrm{P}$ merupakan bahan untuk pembentukan ATP yang berfungsi dalam proses fotosintesis. Hal ini sesuai dengan pendapat (Fitter dan Hay 1991) bahwa ATP yang cukup akan menyebabkan serapan hara oleh tanaman meningkat sehingga hasil polong meningkat.

\section{Berat Polong Isi /tanaman}

Berdasarkan hasil analisis ragam, dapat diketahui bahwa kombinasi dosis pupuk $\mathrm{N}$ dan $\mathrm{P}$ memberikan pengaruh nyata terhadap terhadap berat polong isi kacang tanah. Perlakuan yang terbaik adalah $\mathrm{N}_{1} \mathrm{P}_{3}$, Hal ini menunjukkan bahwa dosis $300 \mathrm{~kg} \mathrm{ha}^{-1}$ SP-36 merupakan dosis pupuk yang terbaik dibanding 100 dan $200 \mathrm{~kg}$ ha- ${ }^{1}$ SP-36.

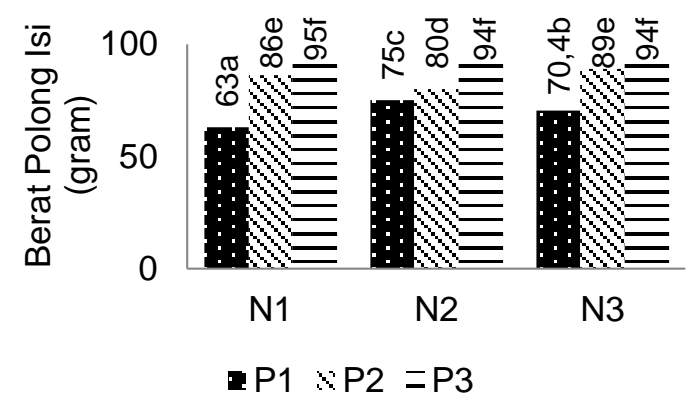

Gambar 3. Pengaruh kombinasi dosis pupuk $\mathrm{N}$ dan $P$ terhadap berat polong isi kacang tanah/tanaman (gram).

Unsur $\mathrm{P}$ digunakan untuk membentuk ATP yang digunakan tanaman untuk energi dalam proses fotosintesis sehingga apabila ATP tercukupi maka proses fotosintesis akan berjalan dengan baik dan hasil fotosintesis meningkat. Keberadaan pupuk $P$ didukung pupuk $\mathrm{N}$ yang diberikan yang dapat dimanfaatkan tanaman untuk bahan dalam proses fotosintesis sehingga pembentukan polong optimal.

\section{Berat Biji Kering/tanaman}

Berdasarkan hasil anailsis ragam dapat diketahui bahwa kombinasi dosis pupuk $\mathrm{P}$ dan $\mathrm{K}$ memberikan pengaruh yang nyata terhadap berat biji kering kacang tanah. Kombinasi terbaik ditujukkan pada perlakuan $\mathrm{P}_{3} \mathrm{~K}_{3}$ yaitu dosis pupuk $300 \mathrm{~kg} \mathrm{ha}^{-1}$ SP-36 dan $225 \mathrm{~kg} \mathrm{ha}^{-1} \mathrm{ZK}$. Pupuk $\mathrm{P}$ yang diberikan dapat menyupali ATP untuk proses fotosintesis.

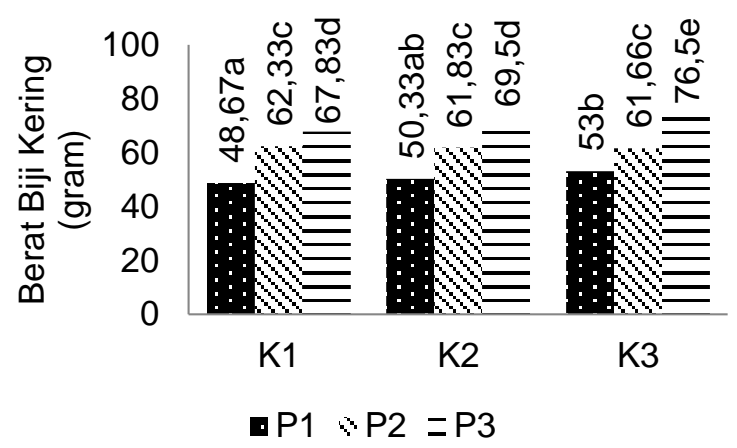

Gambar 4. Pengaruh kombinasi dosis pupuk $\mathrm{P}$ dan $\mathrm{K}$ terhadap berat biji kering kacang tanah/tanaman (gram)

\section{Berat Brangkasan Kering/tanaman}

Berat kering merupakan bahan organik yang terdapat dalam bentuk biomasa. Berat kering menunjukkan proses penangkapan energi oleh tanaman pada proses fotosintesis. Berdasarkan hasil analisis ragam, dapat diketahui bahwa kombinasi dosis pupuk N, P dan K memberikan pengaruh nyata terhadap berat kering tanaman. Adapun perlakuan terbaik yaitu perlakuan $\mathrm{N}_{3} \mathrm{P}_{1} \mathrm{~K}_{1}$, yaitu pemupukan urea sebanyak $150 \mathrm{~kg} \mathrm{ha}^{-1}$, pemupukan SP-36 $100 \mathrm{~kg} \mathrm{ha}^{-1}$ dan pempukan ZK sebanyak $75 \mathrm{~kg} \mathrm{ha}^{-1}$. Hal ini dapat disebabkan dosis pupuk $\mathrm{N}$ yang diberikan tinggi sehingga berat brangkasan tanaman berbeda nyata. Buckam dan Brady (1982) dalam Supramudho (2008), pada tanaman nitrogen berfungsi untuk memperbesar ukuran daun dan meningkatkan prosentase protein. Ukuran daun yang besar dan protein yang banyak akan meningkatkan berat kering tanaman. Hal ini juga dimungkinkan pemupukan dengan $\mathrm{P}$ dengan dosis $100 \mathrm{~kg} \mathrm{ha}^{-1}$ dan $\mathrm{K}$ sebesar $75 \mathrm{~kg} \mathrm{ha}^{-1}$ dapat mendorong fotosintesis tanaman sehingga berat kering tanaman meningkat.

Pupuk $\mathrm{K}$ yang diberikan juga berperan dalam menghasilkan berat biji yang tinggi. Buckman dan Brady (1982) menambahkan bahwa secara garis besar unsur $\mathrm{K}$ memberikan efek keseimbangan baik pada $\mathrm{N}$ maupun $\mathrm{P}$, karena itu $\mathrm{K}$ penting dalam komposisi pupuk campuran. Menurut Novizan (2002), secara umum peranan $\mathrm{K}$ berhubungan dengan proses metabolisme seperti fotosintesis dan respirasi.

Tersedianya hara $\mathrm{P}$ dan $\mathrm{K}$ akan menyebabkan proses fotosintesis berjalanan lancar. Purbayanti et al. (1995) menyatakan $\mathrm{N}$ bersama dengan $\mathrm{P}$ akan membentuk protein, karbohidrat, asam nukleat dan ditranlokasikan oleh unsur $\mathrm{K}$ sehingga berat kering meningkat. 


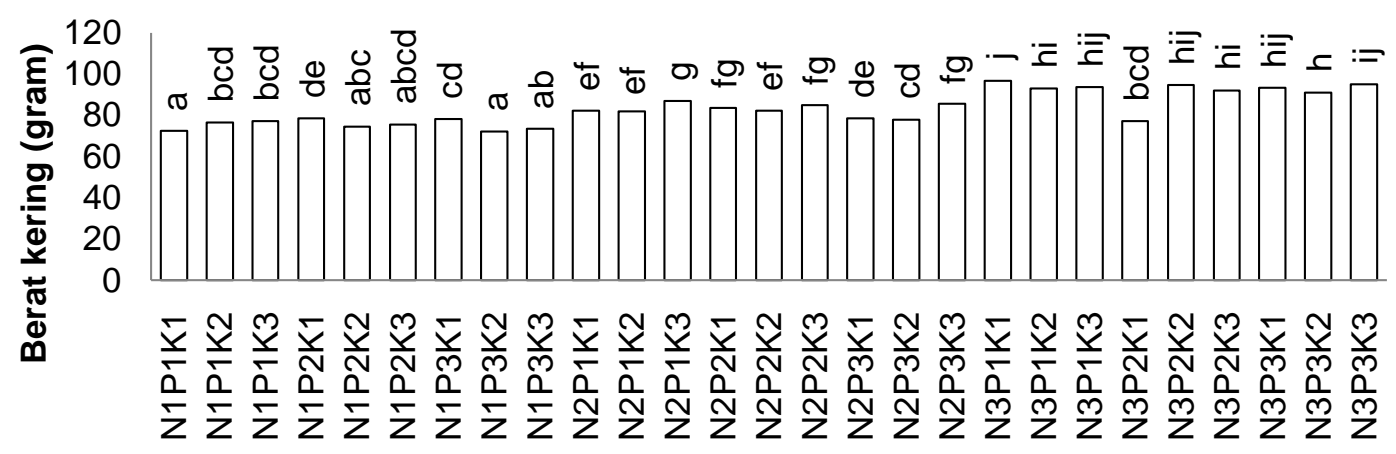

$\square$ perlakuan

Gambar 5. Pengaruh Kombinasi Dosis Pupuk N, P dan K terhadap Berat Kering Brangkasan Tanaman Kacang Tanah/tanaman (gram).

\section{KESIMPULAN DAN SARAN}

\section{Kesimpulan}

Kombinasi dosis pupuk $\mathrm{N}, \mathrm{P}$ dan $\mathrm{K}$ memberikan pengaruh nyata terhadap berat brangkasan kering tanaman kacang tanah. Kombinasi dosis pupuk $\mathrm{N}$ dan $P$ memberikan pengaruh nyata terhadap jumlah dan berat polong kacang tanah. Kombinasi dosis pupuk $\mathrm{P}$ dan $\mathrm{K}$ memberikan pengaruh nyata terhadap berat biji kering kacang tanah.

Dosis $\mathrm{N}$ berpengaruh nyata terhadap berat segar brangkasan tanaman. Kombinasi dosis pupuk terbaik adalah perlakuan $\mathrm{P}_{3} \mathrm{~K}_{3}$ yaitu dosis pupuk $300 \mathrm{~kg} \mathrm{ha}^{-1}$ SP-36 dan $225 \mathrm{~kg} \mathrm{ha}^{-1} \mathrm{ZK}$ yang dapat meningkatkan $57 \%$ berat biji kering jika dibandingkan dengan dosis pupuk rekomendasi.

\section{Saran}

Perlu adanya penelitian lebih lanjut dengan kombinasi dosis ditambahkan perlakuan dosis pupuk organik, sehingga dapat memberikan rekomendasi dosis pupuk untuk tanaman kacang tanah serta dapat menerapkan pertanian berkelanjutan.

\section{DAFTAR PUSTAKA}

Balittan. 2005. Analisis kimia tanah, tanaman, air, dan pupuk. Bogor (ID): Badan Penelitian dan Pengembangan Pertanian Departemen Pertanian.

Brady CN. 1992. The Nature and properties of Soil. New York (NY): Macmillan Publishing Company.

Buckman HO, Brady BC. 1982. Ilmu Tanah (Terjemahan: Soegiman \& Buana I D M). Jakarta (ID): Bhratara Karya Aksara.

Direktorat Jenderal Tanaman Pangan. 2012. Kacang Tanah.http://pusdatin.setjen.deptan.go.id/ditjentp/fil es/Bulletin_Kcang_Tanah.pdf. Diakses pada tanggal 20 Maret 2014.
Fitter AH, Hay RK. 1991. Fisiologi lingkungan tanaman. Yogyakarata (ID): Gajahmada University Press.

Gardner EP, Pearce RB, Mitchell. 1991. Physiology of crop plants. lowa (USA): The lowa State University Press.

Harsono A, Kasno, Winarto, Sunardi. 1993. Gulma pada tanaman kacang tanah. Malang (ID): Balai Penelitian Tanaman Pangan.

Lingga P. 1996. Petunjuk penggunaan pupuk. Jakarta (ID): Penebar Swadaya.

Minardi S. 2002. Kajian Komposisi pupuk NPK terhadap hasil beberapa hasil beberapa varietas tanaman buncis tegak (Phaseoulus vulgaris L.) di tanah Alfisols. J Sains Tanah 2(1).

Novizan. 2002. Petunjuk pemupukan dan efektif. Jakarta (ID) : Agromedia Pustaka.

Prawiranata W, Harran S, Tjondronegoro P. 1991. Dasar-dasar fisiologi tumbuhan. Bogor (ID): Jurusan Biologi Fakultas MIPA Institut Pertanian Bogor.

Purbayanti, Lukiwati dan Trimulatsih. 1995. Dasardasar ilmu tanah. terjemahan dari Fundamentals of Soil Science. Yogyakarta (ID): Gadjah Mada University Press.

Sumampow. 2009. Respon pertumbuhan dan hasil tanaman kacang tanah (Arachis hypogaea). J Soil Anviron 7 (2):165-168.

Supramudho NG. 2008. Efisiensi serapan N serta hasil tanaman padi (Oryza sativa L.) pada berbagai imbangan pupuk kandang puyuh dan pupuk anorganik di Lahan Sawah Palur Sukoharjo. Skripsi. Fakultas Pertanian Universitas Sebelas Maret Surakarta.

Sutarno, Hartono, Sri AR. 1998. Kacang tanah. Bogor (ID) : Balai Penelitian Kacang Tanah. 